\title{
PÄRISNIMEDEST FRIEDRICH REINHOLD KREUTZWALDI KOGUMIKUS ,EESTI RAHVA ENNEMUISTSED JUTUD“
}

\author{
ENN ERNITS
}

\begin{abstract}
Annotatsioon. Kirjutises käsitletakse Friedrich Reinhold Kreutzwaldi kogumikus „Eesti rahva ennemuistsed jutud“ leiduvat nimevara, mis pärineb teose 1866. aasta esmatrükist, kuid analüüsimisel lähtutakse ka August Annisti kommenteeritud tekstikriitilisest väljaandest (1967). Artikli põhieesmärk on vaadelda teoses kasutatud koha- ja tegelasnimesid süsteemselt. Sel otstarbel on teoses lokaliseeritud kõik võimalikud koha-, jumala-, isiku- ja loomanimed, need liigitatud, tehtud kindlaks nende leidumus varasemates eesti keele mälestistes ning võimaluse korral täpsustatud etümoloogiat.
\end{abstract}

Võtmesõnad: eesti keel, kohanimed, isikunimed, muinasjutud, muistendid, Friedrich Reinhold Kreutzwald, onomastika, folkloristika, eesti kirjandus

\section{Sissejuhatus}

Kirjanik ja arst Friedrich Reinhold Kreutzwald oli esimene, kes hakkas „Maarahva Kasulise Kalendri“" lisas, eeposes „Kalevipoeg“ ning kogumikes „Sipelgas“ ja „Eesti rahva ennemuistsed jutud“ (edaspidi EREJ) rahvale selgitama suulise pärimuse rahvuslik-ajaloolist ja poeetilist väärtust ning ärgitas esimesena koguma rahvaluulet. EREJ on „Kalevipoja“ kõrval Lauluisa teine silmapaistvaim teos. Selle aluseks sai rahvapärane aines noorpõlvest mällu talletunud muinasjuttude ja muistendite näol. Lugusid töödeldi romantilise koolkonna eeskujul, kusjuures mõnel määral laenati sobivaid motiive ja süžeesid teiste rahvaste kirjasõnast. Kitsastest avaldamisoludest johtuvalt ilmus teos esialgu annetena (I - 1860, II - 1864, III - 1865). Need sisaldasid üksnes 11 muinasjuttu. 1866. aastal avaldas Soome Kirjanduse Selts Helsingis pealkirja „Eestirahwa Ennemuistesed jutud“" all 43 muinasjuttu ja 18 paikkondlikku juttu ehk kohamuistendit. 
See oli toona kõige mahukam algupärane kirjandusteos eesti keeles. 1875. aastal avaldati Tartus raamatust teine ja 1901. aastal kolmas trükk. EREJ kujunes tolle ajajärgu üheks loetavaimaks raamatuks (EKA II: 105-107, 403).

Teos pole oma menu kaotanud tänapäevalgi. Seni on eesti keeles ilmunud tosinkond trükki, viimati 2009. aastal, lisaks üksikjutte või väiksemaid kogumikke. Oluline etapp oli EREJ sajanda ilmumisaasta puhuks 1967. aastal välja antud ja rahvaluuleteadlase August Annisti kommenteeritud tekstikriitiline väljaanne, mis stabiliseeris järgnenud trükkide keelekasutuse. E-kataloogi „Ester“ andmeil on tänapäeval tehtud algust e-raamatuga (2012) ja publitseeritud lood helisalvestisena (1997-1998). Teos on avaldanud suurt mõju mitme kirjaniku (Jakob Tamm, Marie Under jt) loomingule, olnud aluseks näidenditele, muusikavormidele jm. ${ }^{1}$ EREJ lugusid on tõlgitud mitmesse keelde (inglise, leedu, läti, soome, vene jt). Kokkuvõttes on teosel ,kaalukas koht kogu maailma muinasjutukogude reas" (EK: 69-70). See on eesti kirjanduse tüvitekste. EREJd on Annist mitmes plaanis põhjalikult uurinud püsiva väärtusega monograafias „Friedrich Reinhold Kreutzwaldi muinasjuttude algupära ja kunstiline laad“"(1966).

Enam kui pooleteise sajandi vanune muinasjuttude ja muistendite kogu pakub ikka veel uurimisainet. Seekord tulevad vaatluse alla EREJs sisalduvad koha- ja tegelaskujude nimed. Neid on omal ajal osaliselt käsitlenud Annist mainitud monograafias, kuid terviklik ülevaade puudub. Ka otse rahva seast pärinevate muinasjuttude nimevara on vähe uuritud. Seda teemat algatava pikema kirjutise kokkuvõttes on folklorist Risto Järv (2005: 557) lausunud: „Kuigi nime võib pidada muinasjutu süžee seisukohalt väheoluliseks ja vähekasutatavaks, avab nimi uurija jaoks üsna laia probleemikompleksi.“

Siinse kirjutise põhieesmärk on EREJs mainitud pärisnimede süsteemne käsitelu. ${ }^{2}$ Sel otstarbel on teoses lokaliseeritud kõik võimalikud

1 Siinpuhul võib huvi pärast märkida EREJ ainetel 2018. aastal ilmunud Indrek Hargla koostatud ulmeantoloogiat (VJ).

2 Artikkel põhineb kahel ettekandel, millest üks peeti F. R. Kreutzwaldi mälestuspäeval, 14. XII 2016 Võrus Kreutzwaldi memoriaalmuuseumis ja teine 10. VIII 2018 Eduard Ahrensi päeva III konverentsil Kuusalus. Ettekande teema pakkus välja Kreutzwaldi memoriaalmuuseumi direktor Aimi Hollo, kes ühtlasi esitas palve esineda EREJ ilmumise 160. aastapäeva puhul. Autor on väga tänulik käsikirja 
koha- ja tegelasnimed, need klassifitseeritud, tehtud kindlaks nimede leidumus varasemates eesti keele mälestistes ja võimaluse korral täpsustatud nende etümoloogiat.

Uurimuses lähtutakse esmatrüki EREJ (1866) nimedest ja neid võrreldakse erinevuste korral tekstikriitilise EREJ (1967) nimevaraga. Seevastu tekstinäiteid tuuakse üksnes esmatrüki järgi. Põhiliselt erineb nende õigekirjutus suur- ja väiketähe tarvitamise, kokku ja lahku kirjutamise ning $w$ ja $v$ kasutamise poolest. Kõik pärisnimed esitatakse nominatiivis. Kirjutises ei näidata kõiki raamatukohti, kus nimi esineb, vaid peaasjalikult üksnes nime esmamainingu asukohta. Leheküljenumber lisatakse enamasti sulgudes, kusjuures kaldkriipsu ees asub EREJ 1866. aasta ja kaldkriipsu järel EREJ 1967. aasta väljaande leheküljenumber. Kaldkriipsu puudumisel on tegu esmatrüki leheküljenumbriga. Teose eessõnas ja EREJ 1967. aasta väljaande lisana esitatud varem publitseerimata kohamuistendite nimevara jääb vaatlusest kõrvale.

\section{Kohanimed}

Nimesid sisaldab 43-st EREJ muinasjutust $31(72,1 \%)^{3}$ ja loomulikult kõik 18 kohamuistendit. Siinkirjutaja leidis muinasjuttudest 17 ja muistenditest 30 kohanime, seega kokku 47 toponüümi (tabel 1, k.a kujuteldavate kohtade nimed, kuid mitte umbmäärased kohanimed). Nende hulgas saab eristada maade, piirkondade, linnade, järvede ja muude kohtade nimesid, kusjuures maa-osisega nimed, nagu Rootsimaa, Soomemaa, käsitletakse nimevariantidena, mitte aga eraldi nimedena. Ainult väike osa toponüüme on muinasjuttudel ja muistenditel ühine.

EREJ toponüümide analüüsimisel tuleks tähele panna, kas need on konkreetse muinasjutu tegevuskoha nimed või esinevad tekstis episoodiliselt. Näiteks Kungla(maa) on muinasjuttudes „Nupumees“ ja

kahele anonüümsele retsensendile, kelle soovituste toel sai kirjutis tunduvalt paremaks.

3 Nimed puuduvad järgmistes lugudes: „Kaksteistkümmend tütart“, „Kuidas üks vaenelaps kogemata õnne leidis“, „Haruldane naise truudus“, ,Kuidas üks kuningatütar seitse aastat oli maganud“, „Võõrasema“, „Vägev vähk ja täitmatu naine“, „Leitud laps“, „Julge rehepapp“, „Naljakas härjamüümine“, „Öösised kirikulised“, „Küti kadunud õnn“ ja „Hädaohust pääsenud kuningapoeg saab vendadele päästjaks“. 
„Tuhkatriinu“ üsna kõrvaline. Viimases jutus mainitakse üksnes, et kosilane oli ehk Kunglamaalt pärit (EREJ 1967: 128). Seevastu muinasjutus „Pilli-Tiidu“ toimubki osa tegevust Kunglamaal. Esimesel juhul jääb maa asukoht teadmata, teisel juhul on Annisti (1966: 212, 239, 314) arvates tegu Gotlandi saare ehk Ojamaaga. Seevastu muinasjutus „Kergejalgne kuningatütar" on kirjutatud, et Juba tük aega keeritas üks sääsk Babiloni linna torni ümber (67), mille Teravsilm ambus surnuks, oletatavasti kusagilt Eestist lastes. Rohkem seda linnanime jutus ei kohta. EREJ muinasjuttudes leidubki peamiselt episoodilisi toponüüme.

\subsection{Muinasjuttude kohanimed}

EREJ muinasjuttudes mainitud maade ja piirkondade nimede hulgas saab eristada reaalselt eksisteerivate ja kujutletavate maade nimesid, lisaks leidub paar nn umbmäärast nime. Muinasjuttudes esineb 17 kohanime, millest ligemale poole (8) moodustavad maade nimed. Veel on mainitud kolme linnanime. Ülejäänud kuues objektirühmas (mõis, järv jne) on igaühes nimetatud vaid ühte kohta.

\subsubsection{Reaalsete paikade nimed}

EREJ reaalsete kohtade nimed jagunevad maade, piirkondade, linnade, järvede jm nimedeks.

2.1.1.1. EREJs leiduvad järgmiste, meile enamjaolt suhteliselt lähedaste maade nimed: Kuura $\sim$ Kuuramaa, Pohlamaa, Soome $\sim$ Soomemaa, Rootsi ja Türgi Türgimaa.

Kuuramaa esineb vaadeldavas teoses vaid muinasloos ,Härjapõlvlaste riid“"(131). Muid Läti maa-alasid teoses ei mainita. Näiteks Kuura pulma eel on sõnatud: Tahan Kuura- ehk Pohla-maale minna, siis ei ole tal midagi suuremat tarwis, kui jalga maast ülestõsta: silmapilk jõuab ta igatsetud kohta. Pika $u$-ga vorm oli kaua enne EREJ ilmumist tuntud ja pärastpoole ka rahva seas levinud. Nii on juba Hupelil 1780. aasta vanas kirjaviisis avaldatud sõnastikus Kura ma [= Kuura maa] (AH: 195). Ka Berend Gildenmanni esimeses geograafiaõpikus, mis ilmus 1849. aastal samuti vanas kirjaviisis, esineb identne kirjapilt Kura [= Kuura] kubb(ermang) (BG). Eesti rahvalauludes, mis on talletatud peamiselt XIX sajandi viimasel veerandil või hiljemgi, kasutatakse rohkesti mõlemat nimekuju, nii 
Kura kui ka Kuura, vrd Mis o[n] tamme Kura tamme / Kura tamme, kuiva tamme (Karuse, 1889; ERL I 279, nr 758: 8-9) ja lähme kuuks Kuuramaale, suveks lähme Soomemaale (Haljala, 1889; ERL III 314, nr 4664: 4-5).

Tabel 1. Muinasjuttudes ja muistendites nimetatud kohad

\begin{tabular}{|l|c|c|c|}
\hline \multirow{2}{*}{ Tegevuskoht } & \multicolumn{2}{|c|}{ Arv } & \multirow{2}{*}{ Kokku } \\
\cline { 2 - 3 } & Muinasjutud & Muistendid & \\
\hline Maa või riik & 8 & 4 & 12 \\
\hline Linn & 3 & 5 & 8 \\
\hline Mõis & 1 & 7 & 8 \\
\hline Järv & 1 & 4 & 5 \\
\hline Piirkond & 1 & 3 & 4 \\
\hline Küla & - & 2 & 2 \\
\hline Sild & 1 & 1 & 2 \\
\hline Mägi & 1 & 1 & 2 \\
\hline Mets & 1 & - & 1 \\
\hline Kirik & - & 1 & 1 \\
\hline Veski & - & 1 & 1 \\
\hline Tiik & - & 1 & 47 \\
\hline Kokku & $\mathbf{1 7}$ & $\mathbf{3 0}$ & 1 \\
\hline
\end{tabular}

Pohla-maa (131) tähendab teadupoolest Poolat (vt näidet Kuramaa kohta). Teadaolevalt pärineb kohanime vanim kirjapanek Pola XVII sajandi algusest pastor Georg Mülleri käsikirjalisest jutlusetekstist (GM: 271): oli ju toona suur osa Eesti alast vaheldumisi poolakate ja rootslaste käes. $h$-ta nimekuju Pola Ma esineb ka Gildenmannil (BG). Muide, varem näikse rohkem kasutatud olevat $h$-list kuju, nt Pohla ma (SV: 185), 1732 pohla-ma (ATH: 160), pohla ma, kuid samas ka Pola ma (AH: 245, 246). Nimekuju tekke on vist põhjustanud sarnane sõna pohl : pohla, vrd pohlakas 'poolakas; pohl' (AH: 245). Eesti regilauludes esineb üsna sageli nii Poolamaa kui ka Pohlamaa, nt Nüid ma lähen Lätimaale, pooleks aastaks Pohlamaale, eluks a[j]aks lään [= lähen] Hiiumaale (Ambla 1890; ERL III 896, nr 6507: 32-34).

Soome $\sim$ Soome-maa $\sim$ Soomemaa leiab mainimist EREJ seitsmes muinasloos, milleks on „Kullaketrajad“ (6/12), „Kuu valgel vihtlejad neitsid“(13/19), „Vaeselapse käsikivi“ (43/50), „Paristaja poeg“(120/132), 
„Rohkesti tasutud heategu“(127/141), „Põhja konn“(220/232) ja „Kuidas üks kuningapoeg karjapoisi-põlves üles kasvas“ (287/302). Enamasti on need mainingud seotud Soome targalt või manatargalt abi saamisega, nt Saatke kohe Soome-maale wana targa taadi järele (6). Ainult ühel juhul on seos teistsugune: läks põhja poole Soome rajale (120), seega mitte päris Soome, vaid selle piirile. Kõnesolev kohanimi esineb juba Johannes Gutslaffi lõunaeesti keele grammatikas kujul 1648 Sômamah (JG: 213), samuti Salomo Heinrich Vestringi eesti-saksa sõnastikus 1720-1730 Some Ma (SV: 229) ja ilmselt tema järgi valitult Thor-Hellel 1732 somema (ATH: 179).

Rootsi kasutamine on suhteliselt harv. Jutus ,,Tontla mets“" lausutakse, et Rootsi kuningas oli mitukord käsku annud, kardetud metsa ärahäwitada (33), ning muinasjutus „Näkineitsi“ (179) mainitakse, et kaua enne Rootsi aega, st väga ammu, muiste. Rootsi aeg on Eesti puhul dateeritav XVIXVIII sajandiga. Vaatlusalust kohanime kohtame varasemas eestikeelses kirjasõnas üsna tihti. Esimest korda esineb see aastatel 1550-1570 kirjutatud vandes ,Juramentum der Vndudeschen“ käändevormina Rottsehl Rickes 'Rootsil riigis' (EKVT: 79). Georg Mülleri jutluste käsikirjas on see pandud kirja varieeruval kujul 1600-1606 Rothze $\sim$ Rōtze $\sim$ Rotße $\sim$ Rotze (GM: 301); olgu siinkohal näidetena toodud veel 1632 rotsche 'Rootsi' (JR: 311) ja 1648 Rôtzimah (JG: 237).

Kohanimi 1866 Turgi Turgimaa, 1967 Türgi Türgimaa esineb üksnes loos „Kuidas seitse rätsepat Türgi sõtta lähevad“ (242/255, 249/261). Tegu on saksa repertuaarist laenatud looga, mille ühendamist Türgi sõjaga peetakse Kreutzwaldi loominguks. Annisti (1966: 195, 314) arvates sai Türgi tuntuks eriti alates Krimmi sõjast Venemaa ja Türgi vahel aastatel 1853-1856, kuid kõne alla võivat tulla ka varasemad sõjad. Kohanime ongi kasutatud tunduvalt varem. See oli tuttav juba XVII sajandi alguses Müllerile ja tema vahendusel vähemalt Tallinna Pühavaimu kogudusele kujul Türcke 'Türgi' (GM: 377). Hiljem kajastub sõnaraamatutes rahva ja rahvuse nimetus, nagu 1632 Türcki 'türklane' (JR: 396), 1720-1730 Turk (SV: 261), turk 'türklane', 1732 türki-rahwas 'türklased' (ATH: 193) ja 1780 turk, turki rahwas (AH: 291), ent Gildenmannil siiski 1849 Türgima (BG). Teadaolevalt on $\ddot{u}$-line kuju laenatud saksa keelest, $u$-line aga vene keelest. Kohanimi esineb sageli XIX sajandil talletatud regilauludes

${ }^{4}$ SVs leiduvate sõnade dateerimisel on trükiruumi kokkuhoiu mõttes aastaarve 1720-1730 kasutatud sisuliselt täpsema vahemiku 1720ndad-1730ndad asemel. 
nii Turgi $\sim$ Türgi kui ka Turgimaa $\sim$ Türgimaa kujul, nt Meid on viidud Venemaale, / saadetud meid Saksamaale, / tuubitud meid Turgimaale (ERL II 718, nr 3628: 10-12) ja Mehed mõtlevad metsa suitsu, / naised Narva linna suitsu, / tüdrukud mõtlevad Türgi suitsu (Karuse 1889; ERL III 737, nr 5987: 13-15).

2.1.1.2. Eesti konkreetse piirkonnana on nimetatud Alutaga muinasloos „Tontla mets“: Wanal ajal seisis Alutaga üks ilus metsasalk (33), samuti „Puulases ja Tohtlases“: Kaugel A lutag a elas üks kuulus tark (57). Siinkohal on asjakohane märkida, et kohakääne on lõputa, nime käsitletakse kui kirjeldavat alu taga (see ilmneb ka regilaulus; vt näiteid allpool). Lisaks oleks huvitav teada saada, mis kohta on mõeldud. Nimi esineb ka „Kalevipojas“: Alutaga elas tarka (XV-701). Annisti arvates on viimasel juhul tegu muistse Alulinna linnusega Lüganuse kihelkonnas ühel soosaarel Aa mõisa lähedal ja ta põhjendab seda arvamust faktiga, et Kreutzwald oli varem seda kohta külastanud ja Inlandis kirjeldanud (Kp I: 484). Nimetatud saksakeelses ajakirjas (1838, nr 36) nentis Lauluisa, et nime Alo-linn kandva linnuse varemed paiknevad Virumaa ja Alutaguse piiril, mistõttu selgub, et seda kohanime peab seletama eestikeelse Alo-taguse-maa maakonnanimetusega (Kreutzwald 1953: 79).

Öeldu näitab, et kirjutise autor hoidis muinaslinnuse ja piirkonna nime selgesti lahus. Seega peaks nii „Kalevipojas“ kui ka EREJs olema see hoopis metsane Alutaguse piirkond. Sellele ei räägi vastu ka rahvalaulud, mille ERLi tekstid pärinevad Kirde-Eestist, v.a üks Kuusalu laul (ERL III 936, nr 6606: 3), nt Vilu veeb sõnad Viruje, / halla veeb Alutahaje (Haljala 1892-1894; ERL I 105, nr 141: 8-9); Jõed said suured Jervamaale, / allikad Alutahaje (Kadrina 1869; ERL II 331, nr 2461: 27-28); Ju Virussa söödud lõunat, / ju Virussa, ju Jõvissa, / ju ammu Alutagana (Jõhvi 1888; ERL II 542, nr 3150: 3-5). Regilauludki viitavad piirkonnale, osutades, kuidas nimi on varem käändunud -taga lokatiivne tagana : -tahaje. Kindlust lisab ka kohanime kasutamine varasemas ajakirjanduses, nt 1926 ,Rukkisaak Alutaga keskmine“ (RAK). Vastavust Alutaguse võib tüpoloogiliselt võrrelda teiste kohanimedega, nagu * Sookalda (1582 Sokald) $\sim$ Sookalduse, Soontaga $\sim$ Soontagutse $(1782$ Sontago $\sim$ Sontagusse) ja Sootaga (1796 Sootagga, 1913 Sootaguse) Sootaguse (1726 Sotaga) (EKNR: 617, 619, 621). Alu-osise päritolu pole üheselt selge. Uurijad on seostanud selle kas isikunimega Alo $\sim A l u$ või üldsõnaga $a l u$ 
'soo' (alates Kreutzwaldist), ent sõna alu on leitud vaid ühest kohast (Valjala) ja sellele omistatud tähendus on kahtlane, mistõttu on nimeteadlane Marja Kallasmaa pakkunud võimalikuks tähenduseks hoopis 'alune' (EKNR: 40). Siinkirjutaja jätab siiski hülgamata ka isikunimelise lähte. Sel juhul oleks primaarne Alulinn, st Alole kuulunud või Alo rajatud linnus. Alutaguse oleks väljajätteline kuju oletatavast esialgsest nimest *Alulinnataguse.

2.1.1.3. Linnanimedest mainitakse muinasjuttudes episoodiliselt vaid kolme, milleks on Narva, Rooma ja Babilon. Eesti linnadest on EREJ muinasjutus „Pilli-Tiidu“ nimetatud üksnes Narvat: Viimaks jõudis ta Narva linna (297). Muu maailma linnadest on kõne all Rooma (67) ja muistne 1866 Babilon, 1967 Babülon (67/75), mis esinevad muinasloos „Kergejalgne kuningatütar“: Rooma linnas istuwad praegu wiis kuningast isekeskis koos (näitelause teise linna kohta leiab eestpoolt). Mõlemad linnanimed olid rahvale tuntud piibli põhjal. Need leiduvad juba XVII sajandi kirjamälestistes, sh esimene toponüüm kujul 1600-1606 Rohm, saksapärane Römere Römerÿ (GM: 301), 1632 Roma (JR: 311), 1686 Romast (seestütlevas käändes; WT: 265 jt; Ap. 18.2), teine aga kujul 1604 Babÿlone (GM: 51), 1632 Babyloni Babiloni (omastavas käändes; JR: 59) ja 1686 Pabilon (WT: 471; Ilm. 14: 8 jt). Mõlemat on 1849. aastal maininud Gildenmann kujul Room (vrd sks Rom) ja Pabeli lin. Muide, Rooma linna vastu on Kreutzwald tundnud erilist huvi, jutustades sellest pikemalt teoses „Maailm ja mõnda“ (1849 Roma linn; MM: 46 jj).

2.1.1.4. Veekogunimedest leiab mainimist üksnes 1866 Peipse järw, 1967 Peipsi järv (250/262) muinasjutus „Kuidas seitse rätsepat Türgi sõtta lähevad“. Selle nime kasutamine on Kreutzwaldi mugandus, mispuhul lähtus ta saksa rahvanaljandist seitsme švaablase juhtumiste kohta, milles kõneldakse hoopis Austria, Saksamaa ja Šveitsi piiridesse jäävast Bodenist (Annist 1966: 192). Peipsit on sõnastikus samuti kujul 1720-1730 Peipse Järw nimetanud juba Vestring (SV: 175). See nimekuju esineb üsna sagedasti hilisemas kirjasõnas. Sama tendents ilmneb ka XX sajandi eesti murrakutest, nt Iisaku Peipse järv (KN). 


\subsubsection{Umbmäärased kohanimed}

Nn umbmäärased kohanimed tähistavad suuna järgi umbkaudu lokaliseeritavat territooriumi. Need polegi nagu päris toponüümid, kuid on XX sajandil kirjutatud suure algustähega: 1866 lõunemaa, 1967 Lõunamaa (87/98); 1866 põhjamaa, 1967 Põhjamaa (26/33) ja Lääne rand (179), nt Ma olin seitsmesaa aasta eest lõunemaal rikas kuningas (,Kivialuste ristitütar", 87), teada saiwad, kuda ühe rikkama kuninga tütar põhjamaal („Pikkjalg, Osavkäpp ja Teravsilm“, 26); Kuri põhja madude-kuningas („Kivialuste ristitütar“, 87) ning Lääne rannas elanud wanal ajal üks kaunis näki neitsi („Näkineitsi“, 179). Viimases näites peetakse silmas ilmselt Lääne-Eesti rannikut. Lõune on murdevorm, mida kasutatakse nii Lõuna- kui ka Kirde-Eestis (EMS V: 638). Vanemas eestikeelses kirjasõnas peegeldub praegustel andmetel üksnes Põhjamaa kujul 1720-1730 Pohjama (SV: 185) ja 1732 pohja-ma (ATH: 160). Tänapäeval alustataksegi sõnu põhja- ja lõunamaa 'põhjas või lõunas asuv maa' väiketähega (vt ÕS: $511,749)$. EREJ uustrükkides tulekski nõnda toimida. Ka selle kirjutise nimestatistikas jäetakse mainitu tähelepanuta.

\subsubsection{Kujutletavate kohtade nimed}

Kujutletavate kohtade nimede hulka kuuluvad Kivialuse, Kullamaa, Kungla, Mana (?), Piirisilla, Tontla ja Udumäe.

Väikese algustähega kullamaa esineb esmatrüki muinasjutu „Tänulik kuningapoeg“" alguslauses (151/162): Ükskord oli üks kullamaa kuningas metsa laanes äraeksinud. Nimi Kullamaa on tõlkelaen saksa keelest (Goldland) ja tähistab mütoloogilist kullarikast kohta. See pole seotud Läänemaa Kullamaaga, mis kandis alguses nime *Kultanmäki (EKNR: 252).

Annist (1966: 210) samastab Kungla kullamaaga. Koht 1866 Kungla maa $\sim$ Kungla-maa $\sim$ Kunglamaa $\sim$ Kungla, 1967 Kunglamaa esineb muinasjuttudes „Nupumees“ (88/99), „Tuhka-Triinu“(116/128) ja „PilliTiidu“"(297/311), sh Kalewi poja päiwil elas Kungla maal üks wäga rikas kuningas (88); kõige rikama kuninga tütar, kas ehk Kungla maalt olla (116); rahwa suus elawad jutud kuulutasid mõnda tüki Kungla-maa rikusest (297). Samuti kohtame „Pilli-Tiidus“ fraasiosa kui laew mõne pääwa pärast Kungla randa [oli] jõudnud (298). Eesti regilaulude andmebaasis esineb Kungla kümnes rahvalauluteisendis, nt Eha Narva hallikusta, I 
Koit Kungla kodadesta / Tähed tõistre tammi alta (E 8943 (32) < Paistu khk - J. P. Sõggel (1893)) või kübar mul Kungla kullasta (Paistu 1889; ERL II 257, nr 2230: 15). Usutavasti on Kungla nimetamise rahvalauludes esile kutsunud Kreutzwaldi teosed.

Kungla on eestlaste romantiseeritud kujutlus müütilisest rikkuse- ja õnnemaast (Annist 1966: 210). Selle nime loojaks peetaksegi Lauluisa. Annisti väitel mõtles Kreutzwald Pilli-Tiidu loos Kungla all viikingiajal jõukat Gotlandi saart ehk Ojamaad. Nimetatu esineb ka „Kalevipojas“, nt Tuli Kungla kuninga poeg (Kp I: 499), mispuhul folklorist oletas, et koht on arvatavasti võetud ,mõnest muinasjutust mingi ebamäärase imemaana, kus kõik on kullast vms“" (Annist 1966: 212, 239, 314; Kp I: 439-440). Selge on vaid, et nimi on tuletatud kohta näitava la-liite abil. Ent mida tähendab tüvi kung-? Annisti arvates pärineb see küsimärgiliselt sõnast kuningala. Kunstiteadlane Jüri Kuuskemaa on aga lähtunud rootsi keelest, mainides, et „Kungla rahva jutt läheb 1684. aasta reduktsiooni, olime det kungliga folket 'kuningarahvas'. Sealt see unistus vabaks saamisest" (Raun, Kund 2013). Nõnda siis on mõlemal juhul Kungla tuletatud kuningat tähistavast sõnast, mis on eesti keeles teatavasti juba alggermaani laene (EES: 192).

Mõneti keeruline lugu on mütoloogilise nimega Mana muinasjutus „Pikkjalg, Osavkäpp ja Teravsilm“: kust teda muud ei jõua peasta kui Mana tarkuse wägi (25). Mana (lane) on EREJ (1967: 425) järgi maa-aluse surnute-asukoha elanik või surmahaldjas, kuid õigekeelsussõnaraamatu (ÕS: 535) põhjal tähendab mana kas manamist või maagilist elujõudu; surnute asupaik on manala ja lahkunu manalamees ehk manalane. Ka mana etümoloogia on ebaselge (EES: 275). Muinasjutt „Kuu valgel vihtlejad neitsid“" sisaldab lauset Kogemata önnel juhtus ta viimaks ühe Soome Mana targaga koku (13). Sõna 1866 Mana tark, 1967 Manatark leidub muinasloos „Tark mees taskus“(197/208). Manatark'manamiste, sõnade abil nõiduja' on EREJ (1967: 425) kommentaari järgi otsustades teist algupära ja sisuliselt seostatav verbiga manama. Selle nime võiks edaspidi kirjutada väikese algustähega. Seevastu Kreutzwald on muinasloos ühendanud nimetu targa Mana tarkuse väega, mis nagu viitaks manatargale, või on ta sõna Mana kasutanud soome mana $\sim$ manala eeskujul allilma tähenduses või hägusalt. Seega on asjaomase sõna paigutamine kohanimede hulka problemaatiline.

EREJ muinasjuttudes mainitakse nelja Kreutzwaldi loodud virtuaalset lokaalset kohanime. Need on Kivialuse, Piirisilla, Udumäe ja Tontla 
(mets). Udumäe kuulub siia tinglikult. Muinasjutus „Kivialuste ristitütar“ on kõne all 1866 Kiwialuse, 1967 Kivialuse (84/94): see on neitside kodu, mida Kiwialuse mõisaks nimetati. Öeldu seostub ilmselt folklorist Matthias Johann Eiseni (1995: 56) teatega, mille kohaselt kividel arvati olevat oma haldjas, keda hüütavat ka kivialuseks.

Toponüümi Piirisilla kohta, mis esineb loo „Pikkjalg, Osavkäpp ja Teravsilm" lauses Ma olen Pi iris illa nõia sulane (26), arvas XIX sajandi Peterburi akadeemik Franz Anton Schiefner, kes oli ilmselt tutvunud EREJga, et see nimi on tuletatud rooma luuletaja, keskaegses Euroopas nõiaks peetud Vergiliuse nimest. Kreutzwald tõlkis kirjavastuses üldsõnad piirisild : piirisilla ja piirisilla nõid saksa keelde ning mainis toponüümi Piirisild Rõuge ja Vastseliina kihelkonda eraldaval Piiriojal (KKv: 422, 424). Annist (1966: 106) pidas Schiefneri oletust õigusega kahtlaseks. Polnud ju keerukas siirata nime kõnealusesse muinasjuttu kas sama või mõne teisegi autorile tuntud piirisilla analoogia alusel. Näiteks on teada Luba ehk Piirisilla veski Viljandi maakonnas Halliste vallas Pornuse külas (Luba). Ahvatlev oleks nimele konteksti arvestades semiootiliselt läheneda, pidades silda kahe maailma (sfääri) ühendusteeks.

Tontla (33) metsast räägitakse samanimelises muinasjutus. Toponüüm on moodustatud kohta näitava la-liite abil ja on paigutatud Alutagusele. Juba muinasloo „Udumäe kuningas“ pealkirjas esineb kohanimi Udumäe (60), mille Lauluisa võis Annisti (1966: 126) arvates tuletada uduhaldjate nimetusest (vt ka Eisen 1995: 66, milles Udumäe kuningas on tõenäoliselt teisene).

\subsection{Muistendite kohanimed}

EREJ kohamuistendites leidub peamiselt reaalsete kohtade nimesid. Neist on kõige rohkem mainitud mõisaid (7), vähem linnu, maid ja järvi. Ülejäänud objektide nimesid on igas rühmas üks-kaks.

2.2.1. Maanimedest esineb kõige sagedamini, nimelt neljas jutus, Rootsi $\sim$ Rootsimaa. Mingit Rootsi kuningat märgitakse lugudes „Vinguv jalaluu“ (340) ja „Narva kaupmehe tütar“ (345). Annist (1966: 236) oletab, et kohanime võis lisada alles Kreutzwald. Teisal on kõne all Rootsi ajast varasem ajajärk („Porkuni preili“, 338), põgenemine Rootsi („Vinguv jalaluu“, 341), Rootsi poolt puhuv tuul („Narva kaupmehe tütar“, 346) ning Rootsi sõjavägi (,Kotka käest päästetud kuningapoeg“, 
353). Põgenemismotiiv seondub ka Soomega: ta üle mere kas Soome- ehk Rootsimaale olla läinud (341). Korra on mainitud kohanime Pohlamaa („Kus Narva endine varandus magab“, 346; näide veidi allpool). Samad toponüümid esinevad ka muinasjuttudes.

Erinevalt muinasjuttudest on kahes paikkondlikus loos nimetatud nime 1866 Wene $~$ Wene maa $\sim$ Wenemaa, 1967 Venemaa: muistendis „Narva kaupmehe tütar" (344/368), kus on kirjas, et [kaubast] teine suurem osa Pihkwa kaudu Wenemaale (344), ja loos „Kus Narva endine varandus magab", milles leiame lauseosa [tulnud] Wene wai Pohlamaalt suure sõawäega kodanikusi riisuma (346). Toponüüm on üsna vana. Mülleril leidub küll üksnes Wennelaße (tegelikult $n$ kriipsuga; GM: 402), kuid Gutslaffil juba 1648 Wennemah: Wennemahlle: Wennemahl: Wennemahlt (JG: 232), edaspidi 1720-1730 Wennema (SV: 286) ja 1732 wenne-ma (ATH: 207).

2.2.2. Haljala märgib piirkondliku toponüümina kohamuistendites „Porkuni preili““ (338) ja „Kodukäijate kütt“ (357) kihelkonda: Wiimaks leitud Haljala kihelkonnast üks wanarauk (338). Lisaks on kahes loos (,Toolse rannamehe tütar“, 349; „Kodukäijate kütt“, 357) tegevuspaiga nimena märgitud Toolse rand. Ainukese kujuteldava toponüümina esineb muistendis „Narva kaupmehe tütar“ Kungla saar (344).

2.2.3. Linnadest tuleb neljas muistendis kõneks 1866 Tallin : Tallinna, 1967 Tallinn, nimelt lugudes „Miks Tallinn iial valmis ei tohi saada“ (336/360), „Mereneitsike ja Palmse härra“ (355/378), „Palmse härra päästab Tallinna vaenlaste käest“ (356/379) ja „Kodukäijate kütt“ (359/382). Kohanimi esineb juba ajavahemikus 1535-1549 kirjutatud nn esimeses ametivandes „Juramentũ der vndudeschen“ omastavalisel kujul tallyna [lynnhall] 'Tallinna linnal' ja aastate 1550-1570 paiku antud teises ametivandes kujul tallÿna [L̈̈nnhall] 'Tallinna linnal' ning hiljem 1603-1605 Mülleril omastavas käändes enamasti kujul Tallinna (EKVT: 61, 79; VAKK).

Linnanimi 1866 Narwa, 1967 Narva leidub muistendites ,Narva kaupmehe tütar“ (344/368) ja „Kus Narva endine varandus magab“ (346/370). Seevastu Tartu („Narva kaupmehe tütar“, 344) ja Võru („Paigast läinud järveke“، 342) esineb kumbki ühes jutus. Toona peeti ja nimetati Võrut õigusega linnakeseks. Ainsa väljaspool Eestit asuva linna nimena esineb 1866 Pihkwa, 1967 Pihkva vilksamisi kahes jutus, sh „Paigast läinud järveke“ (342/368) ja „Narva kaupmehe tütar“ (344/368). 
Nendest toponüümidest leidub varasemas eestikeelses kirjasõnas teateid ainult Tartu kohta. Eestikeelses tunnistuses Sigismundus Awerbachile (1589) on küll saksapärane liinast dörpt 'Tartu linnast' ja [Sündnut] dörpt 'leidnud aset Tartus' (EKVT: 94, 95), ent Gutslaffi lõunaeesti keele grammatikas esinevad juba vormiliselt genitiivne 1648 Darto [sisse] 'Tartusse', Dartu [sissen] 'Tartus' ja Dartu [sissest], pika sisseütleva Dartutte, lühikese sisseütleva Dartó 'Tartusse' ning inessiivne Darttun 'Tartus' (JG: 196, 200, 202).

2.2.4. Paikkondlikes lugudes leidub toponüüme mõisate, külade, loodusobjektide jt kohtade tähistamiseks. Muistendites on mainitud seitset mõisat. Neist kõige sagedasem on Palmse, mis esineb seitsmes paikkondlikus loos, sh üle pooltel juhtudel juba pealkirjas (,Näljaaja mälestuse kivikuhjad“, 351; „Palmse härrade varjaja-vaim“, 352; „Kotka käest päästetud kuningapoeg“, 353; „Mereneitsike ja Palmse härra“, 354; „Kabeli ehitamine“, 356; „Palmse härra päästab Tallinna vaenlaste käest“", 356; „Palmse prouade surma-kuulutajad“, 357). Mõisanimed on veel Jõepere („Vinguv jalaluu“, 339), Kaarepere („Kodukäijate kütt“, 357), Kaarli mõis („,Toolse rannamehe tütar“, 350), Kirupää loss („Paigast läinud järveke“", 343), Porkuni loss („Porkuni preili“", 338) ja 1866 Wastseliina, 1967 Vastseliina („Paigast läinud järveke“, 343/367).

Lõuna-Eestiga, täpsemini Võrumaaga, seostub neist vaid kaks kohanime: Kirupää loss Võru lähedal ja 1866 Wastseliina. Kirupää ametlik kirjapilt on tänapäeval arhailine Kirumpää (linnuse varemed), kuid kohalik hääldus ongi $m$-ita ( $n>m$ konsonandi $p$ mõjul), nimelt Kiräppää $\sim$ kiräbä (EKNR: 210). Vastseliina puhul ei ole täiendsõna mainitud, ent selge on, et tegu on mõisaga (samuti loss), sest Kreutzwaldi päevil seal asulat polnudki (EKNR: 741).

Kohanimedest teisel kohal on mäenimi Laagna, mis esineb lugudes „Miks Tallinn iial valmis ei tohi saada“ (336), „Parknaha-kaupmees“ (337) ja „Palmse härra päästab Tallinna vaenlaste käest“" (356), nt Ülemiste järw Laagna mäelt orgu alla langeks, ja linna kõigega ärauputaks (336). Hiljem on Laagna, mis esineb kahel korral ka „Kalevipojas“(II: 455, XVI: 1031), asendatud EREJs toponüümiga Lasnamägi (vastavalt /360, /361, /379). Annist on pidanud võimalikuks, et Kreutzwald on Laagna ise tuletanud Lasnamäe saksakeelsest nimest Laaktberg (s.o Lagedi mägi), kuid ei ole välistanud ka võimalust, et mäe kohta võidigi kunagi kasutada seda nime Lagedi $\sim$ Lageda asemel. Tänapäeval peetakse tõenäolisemaks soome 
keeleteadlase Lauri Kettuneni lähtumist soome sõnadest laakea 'lai, avar' ja laaka 'lame suur kiviplaat', kusjuures liide -la näitab lokatiivsust (vt EKNR: 294). Seevastu kohanimi Lasnamägi võis Annisti arvates tekkida Laagna ja saksa Laksbergi kontaminatsiooni tagajärjel (Annist 1966: 230-231; Kp I: 446; vt ka EKNR: 305). Lisaks on EREJs nimetatud kaht küla: Aruküla (,Vinguv jalaluu“, 339) ja Raudlepa küla (,,Toolse rannamehe tütar"،, 350).

Mikrotoponüümide hulka kuuluvad väikese algustähega kirjutatud 1866 kotkaweski, 1967 kotkaveski („Kotka käest päästetud kuningapoeg“, 354/377), Kadrina kirik (,Vinguv jalaluu“, 339; „Kabeli ehitamine“, 355), Porkuni tiik (,Porkuni preili““, 338) ja 1866 Waskjalasild, 1967 Vaskjala sild (,,Vaskjala silla piiga“, 347/370).

Kotkaveski olevat EREJ muistendi järgi saanud oma nime nõnda, et Palmse mõisahärra päästnud hõbenööbiga tulistades lendava hiiglasliku kotka käest ühe kuningapoja, kes kukkunud jõkke: Hiljemine lasknud ta sinna kohta, kuhu laps wette oli sattunud, ühe weski ehitada, mis praegu weel alles ja täna pääwani ko tk a we s ki ks kutsutakse (354). See asub Kuusalu kihelkonnas Kotka külas, kus oli juba Rootsi ajal jahuveski (1687 Kotkowetzki), mille järgi küla sai nime (EKNR: 242). Tuleb rõhutada, et tegu on veski nimega, mis tuleks EREJ uustrükkides kirjutada suure algustähega. Seevastu Vaskjala silla piiga lugu seostub samanimelise sillaga üle Pirita jõe sama nime kandvas külas Harjumaal Jüri kihelkonnas, mida XIII-XVI sajandini kutsutigi Vaskjala kihelkonnaks (Vaskjala sild; vt EKNR: 142, 739).

Eespool nimetatud toponüümidest leidub Thor-Helle kohanimede loendis 1732 Kadrina kirrik (ATH: 313) ning järgmised mõisad: Jöepärra m., Kaarle m., Kareberre mõis ja Porkholmi 'Porkuni' (ATH: 310, 313, 315, 316). Enamik väiksemate paikade nimesid pärineb Põhja-Eestist, eriti Kreutzwaldile lähedaselt Virumaalt. Teatavasti oli Kreutzwald sündinud Kadrina kihelkonna Jõepere mõisas, mille piiridesse jäi Aruküla, ja kasvanud Rakvere kihelkonna Kaarli mõisas, mille alla kuulus Viru-Jaagupi kihelkonnas asuv Raudlepa küla. Jõepere mõisa Aruküla liideti 1977. aastal Pariisi külaga. Kaarepere on Harjumaal Jüri kihelkonnas paikneva endise Sausti mõisa varasem nimi, mida olevat mäletatud veel XX sajandilgi. Toolse jääb Haljala kihelkonda (EKNR: 464, 546, 598, 670).

2.2.5. Erinevalt muinasjuttudest esineb paikkondlikes lugudes rohkem järvenimesid. Nimetatud nelja järve hulka kuuluvad 1866 Peipse järw, 
1967 Peipsi järv (344/368), mispuhul lodjad ühte puhku jõe ja Peipse järwe pinda pidanud rõhuma (,Narva kaupmehe tütar“", 344), 1866 Emmujärw, 1967 Emujärv (348/371) ja 1866 Wirtsjärw, 1967 Virtsjärv („Emujärv ja Virtsjärv“, 348/371) ning Ülemiste järv (336), vrd weike hal mehike Ülemiste järwest loos „Miks Tallinn iial valmis ei tohi saada“.

Toponüümi Virtsjärv all mõeldakse Võrtsjärve. Seda on eestikeelses kirjasõnas esmamaininud Vestring kujul 1720-1730 Wirtsjärw (SV: 292). Järve nime algupära selgitamisel on lähtutud kord $i$-, kord $\tilde{o}$-häälikust (vt lähemalt EKNR: 781; seal ka viited asjaomastele töödele). Kumb neist on primaarne? XIII sajandi Henriku Liivimaa kroonika osutab $\tilde{o}$-le (Worcegerwe jt), hilisem saksa nimi aga $i$-le (Wirzsee). Vestringi nimekuju ei saa pidada kaalukeeleks, sest see võib olla saksamõjuline. Paul Alvre lähtus $\tilde{o}$-lisest lähtesõnast, milleks olnud hilisem kitsas murdesõna võrrits 'pillirooväli, umbe kasvava järve kõrkjatihnik', Lauri Kettunen aga sõnast virts : virtsa (vrd Virtsu). Pole välistatud, et hiljem on võrts-tüve tähendus rahva keskel, vähemalt teatud aladel täielikult tuhmunud ning Võrtsjärvest sai Virtsjärv, s.o virtsajärv, ning kirjasõnasse on nii- ja naapidi tunginud paralleelselt nii Võrts- kui ka Virtsjärv. Seda mõtet toetab ka Valgamaal Jeti küla lähedal paikneva väikejärve nimi Virtsjärv ehk Väike-Võrtsjärv, mille vesi olnud enne taseme langetamist 1961. aasta andmetel oranži värvusega (!) ja kaldaveetaimestiku koosseisus kasvanud ohtrasti pilliroogu (Mäemets 1977: 98).

Toponüüm Emujärv on tänapäeva Eesti looduses tundmata. Annisti (1966: 245) järgi võis Emu $\sim$ Emmu (<*emoi 'emake') olla Võrtsjärve muistne paralleelnimi, sest ta ühendab nn suure emana ümbruskonna veed, sh läbivoolava Emajõe, samuti oli Pärnu jõe paralleelnimi kunagi just Emajõgi. Annist lähtus Kreutzwaldi kirjas talletatud, lapsepõlves kuuldud loost Emu- ja Virtsjärvest, samuti Eiseni teostest (vt ka Eisen 1995: 64). Kuivõrd seda lugu võib pidada rahvaehtsaks, on iseasi. Annisti seisukoht on ka praegu aktsepteeritav, vrd nt Emajõgi, Emumägi (EKNR: 67-69).

\section{Muinasjuttude ja muistendite mütoloogiliste tegelaste nimed}

Järgnevalt asugem EREJs leiduvate tegelaskujude nimede vaatlusele. Need esinevad enamasti ainult muinasjuttudes. Siinpuhul saab eristada ühelt poolt jumaluste ja muude mütoloogiliste tegelaste nimesid, teisalt aga 
inimesenimesid. Nende nimede koguarv on 59, kusjuures mütoloogiliste olendite nimed moodustavad ühe kolmandiku (tabel 2).

Tabel 2. Tegelasnimede arv liigiti

\begin{tabular}{|l|c|c|c|}
\hline \multirow{2}{*}{\multicolumn{1}{|c|}{ Jumalus või inimene }} & \multicolumn{2}{c|}{ Arv } & \multirow{2}{*}{ Kokku } \\
\cline { 2 - 4 } & Muinasjutud & Muistendid & \\
\hline $\begin{array}{l}\text { Jumalus või muu mütoloogiline } \\
\text { tegelane }\end{array}$ & 19 & 1 & 20 \\
\hline Inimene tehisnimega & 20 & - & 20 \\
\hline Inimene eesti tavanimega & 15 & - & 15 \\
\hline Inimene võõrapärase nimega & 2 & 2 & 4 \\
\hline Kokku & $\mathbf{5 6}$ & $\mathbf{3}$ & $\mathbf{5 9}$ \\
\hline
\end{tabular}

Jumaluste ja mütoloogiliste tegelaste arv on mõneti problemaatiline, sest alati pole selget piiri päris- ja üldnime vahel, mis on kirjutatud kord väikese, kord suure algustähega (lähemalt allpool). Paristaja-poeg, Pikne, Põhja konn ja Rõugutaja on juttude nimitegelased, kuid ülejäänud nimed ilmuvad enamasti vilksamisi. Sõna jumal Jumal jääb praegusel juhul vaatluse alt välja.

Teadupoolest pärineb osa mütoloogiliste tegelaste nimesid eesti pseudomütoloogiast, millele pani XIX sajandi esimesel veerandil aluse soome rahvausundi teost tõlkides luuletaja ja keelemees Kristjan Jaak Peterson. Selline EREJ episoodiline tegelane on kõigepealt veehaldjas $A h t i^{5}$ (6) (tabel 3). Teda mainitakse muinasjutus „Kullaketrajad“vaid Kreutzwaldi enda loodud sajatusvärssides: Mattis laene lapsukese, / Kattis Ahti armukese (vt ka Annist 1966: 98). Ahti nimi esineb korra ka „Kalevipojas“: Salapeidul sügavusi, / Ahti poja haudasida? (XVI: 71-72). Seni, kuni pole selgitatud soome jumaluse nime päritolu, ei saa selgust selle võimalikust või võimatust seosest kõlalt lähedaste Eesti kohanimedega (vt Kp I: 486; Ernits 2017: 198 jj).

5 Annist (1966: 176) ja EREJ (1976: 372) viitavad Ilmarise nime puhul muinasjutule „Maa-alused“, kuid seal seda nime tegelikult ei leidu. 
Tabel 3. Mütoloogiliste tegelaste nimed ${ }^{6}$

\begin{tabular}{|l|l|c|}
\hline \multicolumn{1}{|c|}{ Nimi 1866/1967 } & \multicolumn{1}{|c|}{ Muinasjutu pealkiri } & Lk \\
\hline Ahti & „Kullaketrajad“ & 6 \\
\hline Kalew/Kalev & - " - & $2 / 8$ \\
\hline $\begin{array}{l}\text { Kalewi poeg / } \\
\text { Kalevipoeg }\end{array}$ & „Nupumees“ & $88 / 99$ \\
\hline - " - & $\begin{array}{l}\text { „Kuidas seitse rätsepat Türgi sõtta } \\
\text { lähevad“ }\end{array}$ & $249 / 261$ \\
\hline Kõwer/Kõver & „Rohkesti tasutud heategu“ & $127 / 140$ \\
\hline Looja & „Helde puuraiuja“ & 320 \\
\hline Murueit & „Kuu valgel vihtlejad“ & 15 \\
\hline - "- & „Nupumees“ & 88 \\
\hline põhja konn & „Põhja konn“ & $209 / 220$ \\
\hline Rõugutaja & „Rõugutaja tütar“ & 175 \\
\hline Tühi & - " - & $123 / 136$ \\
\hline Wanaisa/Vanaisa & - " - & $125 / 138$ \\
\hline $\begin{array}{l}\text { wana taadike Tühi / } \\
\text { vanataadike-Tühi }\end{array}$ & - " - & $123 / 136$ \\
\hline wana Tühi / Vanatühi & - " - & \\
\hline
\end{tabular}

Veidi mõistatuslikuks jääb muinasjutu „Põhja konn“ nimitegelane 1866 põhja kon, 1967 põhja konn (209, 218/220, 228), mis kirjutatakse mõlemas EREJ redaktsioonis väikese algustähega. Annist (1966: 182) on pidanud loo lähteks rahvusvahelise levikuga „Lohetapjat“, milles Kreutzwald lõi lohe asemele tõenäoliselt eestipärasema tegelase, sest põhjamaa on eesti ja soome usundis kõige kurja asupaik. Eiseni arvates peaks sõna konn asemel hääldama peenendatult kon 'n', mis murdes tähendavat kolli, ning Kreutzwald võis rahvalt kuuldud sõna vääriti mõistes muuta selle konnaks. See võib olla tõsi, sest tõepoolest on Lääne-Eestist ja saartelt registreeritud murdesõna konn : konni lastehirmutise tähenduses (EMS III: 559-560), ent kas sealne sõna ka Lauluisa kõrvu ulatus, pole võimalik tuvastada. Teisalt on mõeldav ka sõna varasem laiem levik. Põhja konn võiks ainukordse tegelase pärisnimena olla alustatud suurtähega. Teine lugu on sõnaga põhjakotkas (87), mis Annisti (1966: 135) oletusel pärineb eeposest „Kalevala“(vrd sm Pohjolan kotka). Muinasjutu lausekohta

${ }^{6}$ Välja arvatud kõuejumaluse nimed, mis on esitatud tabelis 4. 
peate ühe kiwikese põhja-kotkaks moondama (86) arvestades on eeskujust hoolimata õigustatud sõna kirjutamine väikese algustähega.

Muinasjutus „Rohkesti tasutud heategu“ küsitakse kaselt heateo eest hüvitise saamiseks: Kas Kõwer kodu[s]?. Annisti (1966: 153) arvates on see mingi kõveraks muutva pahareti peitenimi. Kindlasti huvipakkuv on mõneti mõistatuslik, juba loo pealkirjas sisalduv Rõugutaja (175/186), keda osa teadlasi on seostanud soome viljakushaldja Rongoteusega (etümoloogia kohta vt Annist 1966: 167). ${ }^{7}$ EREJs mainitud Taadike-Tühi, Tühi ja Vanatühi on Vanapagana nimeteisendid.

Muinasloos „Helde puuraiuja“ esineb Looja lauses Mina olen m e ts a is a, keda Looja punde üle wallitsejaks on seadnud (320). Ristiusu tegelasena esineb see vanaeestikeelses kirjasõnas alates XVI sajandi viimasest veerandist, nimelt esimest korda Johannes Ambrosius Völckeri 1585. aasta paiku kirjutatud tekstis, tõsi küll veel üldsõnana taivo nink maha loya (EKVT: 81), seejärel Mülleril Taiwa ninck Maa Lö̈a (GM: 190), Turu käsikirjas 1600-1650 Taiwa n . se mhoa loija (VAKK), Rossihniusel 1632 Taiwa ninck mah Loja (JR: 192). Alles Vestringi sõnastikus esineb nimi isoleeritult: 1720-1730 Loja (SV: 121).

Muinasjutus „Kuu valgel vihtlejad“ on murueit (15) mõlemas EREJ väljaandes trükitud väikese algustähega, mispuhul lauseosa struktuur on veidi iseäralik: Köik need metshalija ja murueide tütred. Eks murueit ise olegi metshaldjas. Seevastu muinasjutus „Nupumees“ on murueit esmatrükis kirjutatud väikese algustähega, hilisemates väljaannetes aga suure algustähega (88/100). Uustrükkides tulekski taastada algne olukord, sest see on üldsõna (ÕS: 573).

Kreutzwald on oma juttudes kasutanud kõuejumaluse ehk äikesehaldja väljendamiseks mitut rahvapärast nime, nagu Kõu, Pikker (tabel 4). Uku esineb teoses ja tegelikkuses üksnes kivi nimes: kui sa teda [= last] iga hommikul lepikusse Ukku kiwi juure tood. Asjaomaseid kive peetakse ilmaja kõuehaldjale Ukule ohvritoomise kohaks (EREJ 1967: 426). Ainuüksi ühe jutu nimitegelane Paristaja-poeg (118) on tõenäoliselt Kreutzwaldil endal tuletatud üldsõnast paristama põristama (Annist 1966: 144).

7 Olgu siinkohal esitatud võrdluseks killuke Jaagup Mahkra ulmejutust „Rõugutaja tütar", kust võime lugeda: ,, Rongutus?" päris Johann, kui ma talle paberit näitasin. „, Rõugutaja, “ tõlkisin ma. „,Nii teda mõnel pool kutsutakse. Ta ei ole siitkandi tütarlaps. “(VJ: 307). 
Tabel 4. Kõuejumaluse nimed

\begin{tabular}{|l|l|c|}
\hline \multicolumn{1}{|c|}{ Nimi 1866/1967 } & \multicolumn{1}{c|}{ Muinasjutu pealkiri } & Lk \\
\hline Kõu & „Paristaja-poeg“ & 119 \\
\hline Kõu taat / Kõue-taat & - " - & $119 / 132$ \\
\hline Paristaja-poeg & - " - & 176 \\
\hline Pikker & - " - & 120 \\
\hline Pikne & „Pikse pill“ & 123 \\
\hline Pikseisa & „Härjapõlvlaste riid“ & 133 \\
\hline Ukku/Uku & „Rõugutaja tütar“ & $176 / 188$ \\
\hline
\end{tabular}

Erinevalt muinasjuttude mütoloogiliste tegelaste suhtelisest rohkusest esineb kahes muistendis üksnes jumalik 1866 wanaisa, 1967 Vanaisa, nimelt lugudes „Paigast läinud järveke“ (344/368) ning „Emujärv ja Virtsjärv“"(348/371).

\section{Muinasjuttude isikunimed}

Järgnevalt tulevad vaatluse alla EREJ muinasjuttudes esinevad antroponüümid, mis jagunevad tavalisteks eestipärasteks eesnimedeks, võõrapärasteks eesnimedeks ja kunstlikult loodud isikunimedeks. Lähemalt käsitlemata jäävad isikunimed, mille täiend on mingi maa nimi, nt Soome tark muinasjutus „Kuidas üks kuningapoeg karjapoisi-põlves üles kasvas“ (287).

4.1. Tavaliste eestipäraste nimede seas saab eristada liht- ja liitnimesid. Esimeste hulka kuuluvad Els, Hans, Jüri, Madli jt (tabel 5). Näiteks loos „Tontla mets“ on kõne all seitsme aastane tütarlaps, Els nimi (34). Nimi käändub Els : Else, nt ütles siis Elsele. Selle jutu faabula pärineb saksa kirjaniku Ludwig Johann Tiecki kunstmuinasjutust „Haldjad“, mille tegelase nimi on hoopis Marie (Annist 1966: 110). Kõik tabelis mainitud nimed on tekkinud kahtlemata võõrnimedest (algupära kohta vt Rajandi 2011).

Mitmele eesnimele on nimekandja lähemaks iseloomustamiseks lisatud täiend, nt hanekarjusel 1866 hanede Tõnu, 1967 Hanede-Tõnu, kelle ristinimi oli Tõnu, kusjuures Kreutzwald, kes lõi Hanede-Tõnu kuju, lähtus Charles Perrault' „Mu ema Hane juttudest“(Annist 1966: 196). Muinasloo 1866 Kawal Hans, 1967 Kaval-Ants on pärit rahvalikust Kaval-Antsu ja Vanapagana sarjast (Annist 1966: 157). Muinasjutus „Maa-alused“ 
mainitakse kaht Hansu, isa ja poega, kusjuures isa kutsuti Pikaks Hansuks: „Mis sul nimi on? “küsis männikepi mees, ja talumees kostis: „, Pika Hansu poeg Hans "; rahvaliku tegelase nime on Annist eestistanud, st viinud vastavusse rahvaluulega, kuid teisel juhul mitte (190/202).

Teatavasti pärineb Tuhka-Triinu (111) samanimelisest rahvusvahelisest muinasjututüübist. Paljudes keeltes seostub peategelase nimi tuhaga, nt saksa Aschenputtel (vrd Asch 'tuhk'), prantsuse Cendrillon (vrd cendre) ja rootsi Askungen (vrd ask; vt Aschenputtel 510A).

Nimede loetellu tuleks lisada veel muinasjutu „Pilli-Tiidu“ nimitegelane ja „Näkineitsi“" 1866 Une Tõnu, 1967 Une-Tõnu, nt Wanemad sõimasiwad teda pääwawargaks ja wennad Une - Tõ n u ks [...] ehk kül teda Jü ri nimeliseks lapselt ristitatud oli (180/191). Selguse mõttes esitame lõpuosa ka Annisti versioonis: ehk küll teda lapsena Jüri-nimeliseks oli ristitud.

Tabel 5. Tavalised eestipärased isikunimed

\begin{tabular}{|l|l|c|}
\hline \multicolumn{1}{|c|}{ Nimi } & \multicolumn{1}{|c|}{ Muinasjutu pealkiri } & Lk \\
\hline Els & „Tontla mets“ & 34 \\
\hline $\begin{array}{l}\text { hanede Tõnu / } \\
\text { Hanede-Tõnu }\end{array}$ & „Naiste mõrtsukas“ & $254 / 266$ \\
\hline Hans & „Maa-alused“ & 190 \\
\hline Jüri & „Näkineitsi“ & 180 \\
\hline $\begin{array}{l}\text { Kawal Hans / } \\
\text { Kaval-Ants }\end{array}$ & „Võllamehikesed“ & $134 / 137$ \\
\hline Madli & „Kivialuste ristitütar“ & 81 \\
\hline Maret & - "- & 81 \\
\hline Mari & - "- & 81 \\
\hline Peeter & „Õnne-rublatükk“ & 254 \\
\hline Pikk Hans & „Maa-alused“ & 190 \\
\hline $\begin{array}{l}\text { Pilli Tiidu / } \\
\text { Pilli-Tiidu }\end{array}$ & „Pilli-Tiidu“ & $295 / 309$ \\
\hline Pärtel & „Õnnemunake“ & 236 \\
\hline Tiiu & „Udumäe kuningas“ & 61 \\
\hline Tuhka-Triinu & „Tuhka-Triinu“ & 111 \\
\hline Villem & „Munast sündinud kuningatütar“ & 312 \\
\hline
\end{tabular}


4.2. EREJ muinasjuttudes leidub kaks täiesti võõrapärast nime, mida pole meil eesnimena vist kasutatud. Mõlemad antroponüümid, esimene, tõsi küll, märksa laiemalt tuntud kui teine, on pärit piiblist, nimelt Salomon (209) ja Nikodemus (90).

Muinasloos „Põhja konn“ võib lugeda, et koleda metsalise üle muidu kedagi wõimust ei wõida saada kui kuninga Salomoni pitseri sõrmukse läbi. EREJ (1967) on säilitanud vanas kirjaviisis nimekuju. Annisti (1966: 184) arvates viitab see tekstikoht kas idamaistele või saksa kirjaniku Wilhelm Hauffi muinasjuttudele. Nimelt suutis Iisraeli kuningas Saalomon juudi või araabia legendis võlusõrmusega käsutada vastavalt rahvale kas deemoneid või džinne (Ring Salomos). Salomon esineb XVII sajandi kirjasõnas juba alates Müllerist (GM: 307; JR: 316; WT: 1, Mt 1: 4 jt).

Haruldasem nimi on ladinapärastatud Nikodemus, õigupoolest küll Nikódemos, mille osised tähistavad kreeka keeles võitu ja rahvast. Ka see antroponüüm esineb piiblinimena eestikeelses kirjasõnas juba alates XVII sajandist: 1632 Nicodemus (JR: 236) ja 1686 Nimmi Nikodemus / Judaliste Pählik (WT: 179, Joh 3: 1).

4.3. Eeltoodule lisaks on EREJs nimetatud inimesi erilise nimega, mis on suuremalt jaolt, kui mitte kõik Kreutzwaldi loodud. Enamasti on need hüüdnimed, nagu Ühe-, Kahe-, Kolme-, Nelja- ja 1866 Wiierammulane, 1967 Viierammulane ning Ninamees ja Sabamees jutus „Kuidas seitse rätsepat Türgi sõtta lähevad“(243/255), samuti 1866 Pikjalg, 1967 Pikkjalg, 1866 Osawkäp, 1967 Osavkäpp ja 1866 Terawsilm, 1967 Teravsilm (17/23), Nupumees (88/99) ning Puulane ja Tohtlane samanimelises loos (57/65), aga ka 1866 Sawine, 1967 Savine muinasjutus „Tontla mets“ (38/45). Ühtlasi iseloomustavad need nimed kõnealuseid tegelasi.

Peale nime Savine on tegu liittüveliste nimedega. Seitsme rätsepa loo on Kreutzwald mugandanud kirjasõna vahendusel tuntuks saanud saksa rahvanaljandist „Seitse švaablast“. Võib-olla on ta nimedki loonud ise, pannud esimesele ja seitsmendale rätsepale nimeks Ninamees ja Sabamees ning seadnud vahepealsed rätsepad järjekorda, väites, et nimed küll seda ei tähendanud, et kellelgi neist kolme ehk nelja mehe rammu oleks olnud, waid aga näitas, kuda nemad järgmiste pidid teel käima, et midagi eksitust ei wõinud tulla, kusjuures sõnakogudes puuduv sõnavorm järgmiste on Annist asendanud sõnaga järgemööda (243/255). See peegeldab mõtlevale lugejale isemoodi nimemoodustusloogikat. Ninamees oli mitmetähendusliku üldsõnana eesti keeles ammugi olemas (vt Wied: 
602), Sabamees aga olemasolevate allikate järgi mitte. Näiteks vendade Grimmide muinasjututeisendis tegutsevad hoopis Schulz, Jackli, Marli, Jergli, Michal, Hans ja Veitli (Gr). Võib-olla sai Lauluisa mõningast eeskuju eesti muinasjututüübist „Ükssilm, Kakssilm, Kolmsilm“või samade nimedega loitsulisest unelaulust (vt EM I: 632-633).

EREJs on nimitegelane Nupumees. Tema kohta öeldakse: Minu ristitud nimi on Nikodemus, aga kodu kutsuti mind ika Nupu-meheks, mis niipalju tähendab, et mu pea ja aru parajal kohal (90/101). Nupumees on tähenduses 'peaga mees, nupukas mees' rahvapärane (Wied: 602). See selgub ka EREJst: Isa nimetas seda poega nupu-meheks, misga ta tahtis, tähendada et pojal rohket mõistust nupus (peas) oli (88/100). Selles alapeatükis esitatud teistele nimedele eeskujude otsimine rahvalikest muinasjuttudest osutuks liiga töömahukaks, mistõttu jääb see praegusel juhul tegemata. Näiteks esindab lugu „Pikkjalg, Osavkäpp ja Teravsilm“ jututüüpi „Kuus üheskoos saavad kõigest ilmast läbi“, millest on üle Eesti talletatud 50 varianti (EM I: 634-635). Suure isuga savimees esineb muide vepsa ja saami muinaslugudes, ent kas ka meil ja kas leidub selle võimalikes teisendites ka nimesid, pole esialgu teada.

Järgnevalt tuleb juttu lihttüvega inimesenimedest, mille hulka kuuluvad Maasikas, Rebuliina ja Kiisike. Kivialuste ristitütar sai samanimelises muinasloos ristimisel nimeks Maasikas (81), mida tavaliselt pannakse punasele lehmale. Munast sündinud kuningatütrele sama nime kandvas muinasloos anti nimeks Rebuliina (312), mis kõlab küll üpris itaaliapäraselt, kuid seostub siiski eesti sõnaga (muna)rebu (Annist 1966: 212).

Kreutzwaldi loodud nimi muinasjutus ,Tontla mets“" on Kiisike: aga üks sõna, mis igast laulust kostis, oli „Kiisike!“. Els küsis, mis se pidi tähendama, ja proua tütar kostis: „, Se on minu nimi“ (36). Siinpuhul ehk lähtuti kassi hellitusnimest kiisi (vrd ka kiis, kiisa, kiisu), millega on seltsinud mõni vana saksa eesnime Gisela või Gislinde hellitusvorm (Gisa; vt Naumann jt 1984: 88; EMS III 99).

Muinaslugu „Lopi ja Lapi“ kujutab endast saksa kirjaniku ja teoloogi Johann Peter Hebeli jutukese „Kolm soovi“"vaba ümbertöötlust, kusjuures originaalis esinevad tavanimed Hans ja Lise (Laugaste 1940: 181, 182; Annist 1966: 132, 133). Kreutzwald pani aga oma tegelastele häälikuliselt kõnekamad nimed: 1866 Loppi, 1967 Lopi ja 1866 Lappi, 1967 Lapi (77/87). Rahvaluuleteadlase Eduard Laugaste arvates on need nimed laenatud soome kirjamehe Andreas (Antero) Wareliuse pikemast 
kirjutisest, mis oli Kreutzwaldile kindlasti tuntud (MK 585, kommentaarid). Mainitud autori etnograafilise kirjelduse allmärkuses kõrvutatakse omavahel Soome toponüüme Lappi 'Lapimaa' ja Loppi 'piirkond Tyrvää kihelkonnas' (Warelius 1849: 88-89). ${ }^{8}$

Sugugi pole selge muinasjutus „Piksepill“ mainitud kalamehe nimi: üks nõukas kalamees, Lijon nimi (124). Nimi pärineb maamõõtja ja rahvaluulekoguja Johan Lagose talletatud tekstist. Lagos oli tuntud ka rahvapärandi ümbertöötajana, mistõttu jääb ähmaseks, kas Lijon (Lagosel: Liijoni ingel) on rahvalik nimekuju või on kasutaja ise selle välja mõtelnud. Esimesena on antroponüümi päritolu käsitlenud Peterburi akadeemik Franz Anton von Schiefner, oletades muinasjututõlke kommentaaris, et nimi on moodustatud kas piibli leegion-sõnast või prohvet Eelija nimest. Tuginedes Uue Testamendi kirjakohtadele (Mk 5: 9, Lk 8: 30), ${ }^{9}$ milles roojane vaim nimetab end leegioniks, oletas Eisen (1920: 99), et Lijoni nimi pärinebki sealt. Eisenile viidates resümeeris Annist (1966: 148-149): „Väherahvalik „Liioni““ nimi on (Lagosel?) tekkinud kas läti „Lihgo“ eeskujul või tõenäolisemalt rahvaliku S i i o n i ingli ja võib-olla ka rahvaliku El i i a s e nime kontaminatsioonist. "Siinkirjutaja arust ei maksaks heita üle parda ka Schiefneri oletust end Leegioniks nimetava ingli kohta. Läti eeskuju võiks ehk kõrvale jätta.

\section{Muistendite isikunimed}

Paiklikes juttudes esineb isikunimesid üsna harva. Inimeste nimedest leidub seal võõrapärased Pahlen ja Pontus. Palmse mõisa omanikust Pahlenist räägitakse lugudes „Palmse härrade varjaja-vaim“ (352/375), „Kotka käest päästetud kuningapoeg“ (353/376), „Kabeli ehitamine““ (355/379) ja „Palmse härra päästab Tallinna vaenlaste käest“ (356/379). Esmatrükis käänatakse esimesena mainitud loos nime Pahlen : Pahlena, teistes lugudes aga, nagu tänapäevalgi, Pahlen : Pahleni.

Kohamuistendis „Parknaha-kaupmees“ kõneldakse Pontusest (337). Tegu on XVI sajandil Prantsusmaalt Rootsi väejuhiks siirdunud ja Tallinna Toomkirikusse maetud Ponce Scorperier'ga, kes sõjateenistuses viibides

8 Laugaste kommentaaris nimetatakse sõnade kõrvutamist eksitavalt sõnamänguks. Annistil jäi kommentaar tähele panemata.

9 Ja küsis temalt: „,Mis su nimi on? “ Ta ütles talle: „, Mu nimi on Leegion, sest meid on palju! “ (Mk 5: 9). 
võttis endale uueks nimeks Pontus de la Gardie (Annist 1966: 228; Pontus de la Gardie; vt ka Palmblad 1838: 78 jj). Pontus on Vana-Rooma nime Pontius Skandinaavia keeltele omane kuju (Name). ${ }^{10}$

\section{Muinasjuttude loomanimed}

Loomanimedest mainitakse EREJs vaid nelja koeranime. Muinasjutus „Õnne-rublatükk“ räägitakse kolmest koerast, nimelt: kuda sa juba kuulid, on esimese koera nimi: Joo ks e-too-s ü̈̈a, keskmisel: Mu r ram a ha, suuremal: Lõ h u ra u a d! (262). Need kirjeldavad nimed ei vaja lähemat seletamist. Nende omapärase struktuuri põhjal (verbid käskivas kõneviisis) arvab siinse artikli anonüümne retsensent, et nad võiksid olla laenud, ent konkreetsete eeskujude avastamine oleks materjali ohtruse tõttu üsna komplitseeritud. Muinasloos ,Vaeselapse käsikivi“ esineb koeranimi 1866 krants, 1967 Krants (43/50), nt tal muud sõbra ei olnud kui perekoer krants. Tänapäeval kasutatakse üldsõna krants koerast halvustavalt kõneldes, varem kindlasti mitte (sõna päritolu kohta vt EES: 181-182).

\section{Kokkuvõte}

EREJs kasutatakse 47 toponüümi, millest 17 muinasjuttudes ja 30 kohamuistendites. Muinasjuttudes eristuvad reaalsed paigad, sh maad, piirkonnad, umbkaudu lokaliseeritavad paigad (nt Põhjamaa) ja virtuaalsed paigad, nagu Kullamaa ja Kungla. Muinasjuttudes leidub toponüümidest kõige rohkem maade nimesid (arvult 8), sh Soomemaa, Pohlamaa. Muistendites räägitakse peale ühe erandi üksnes reaalsetest kohtadest. Neis esineb kohanimedest kõige rohkem mõisate (7), nagu Kaarli, ning linnade (5) nimesid (Tallinn jt). EREJ sisaldab 59 isikunime, millest enamik (56) esineb muinasjuttudes. Need jagunevad mütoloogiliste tegelaste nimedeks (Ahti, Põhja konn jt; arvult 20) ja inimesenimedeks (Els, Une-Tõnu, Pahlen jt; 39). Lisaks leidub EREJs neli koeranime.

${ }^{10}$ Nime lähteks on peetud kas hääbunud oski keele sõna tähenduses 'viies' või kreeka sõna ho póntos 'meri' (vrd ka kreeka merejumala Pontose nime; Name). 


\section{Kirjandus}

AH = August Wilhelm Hupel 1780. Ehstnische Sprachführer für beide Hauptdialekte den revalschen und den dörptschen nebst einem vollständigen Wörterbuch. Riga, Leipzig: J. F. Hartknoch.

Annist, August 1966. Friedrich Reinhold Kreutzwaldi muinasjuttude algupära ja kunstiline laad. Tallinn: Eesti Raamat.

Aschenputtel 510A. http://www.maerchenlexikon.de/at-lexikon/at510A.htm (30.04.2019).

ATH $=$ Anton Thor-Helle 2006 [1732]. Lühike sissejuhatus eesti keelde. Tallinn: Eesti Keele Sihtasutus.

BG $=$ Berend Gildenmann 1849. Mailma made õppetus 1849. http://www.eki. ee/knab/dr/gi1849.htm (12.01.2019).

EES = Eesti etümoloogiasõnaraamat. 2012. Koost. ja toim. Iris Metsmägi, Meeli Sedrik, Sven-Erik Soosaar. Peatoim. Iris Metsmägi. Tallinn: Eesti Keele Sihtasutus.

Eesti regilaulude andmebaas. http://www.folklore.ee/regilaul/andmebaas (12.01.2019).

Eisen, Matthias Johann 1920. Eesti uuem mütoloogia 2. Eesti uuem mütoloogia. Tallinna: K./Ü. Rahvaülikool. https://et.wikisource.org/wiki/ Eesti_uuem_mütoloogia (12.01.2019).

Eisen, Matthias Johann 1995 [1919]. Eesti mütoloogia. 2. tr. Tallinn: Mats.

EK = Epp Annus, Luule Epner, Ants Järv, Sirje Olesk, Ele Süvalep, Mart Velsker 2001. Eesti kirjanduslugu. Tallinn: Koolibri.

EKA II = Eesti kirjanduse ajalugu 2. XIX sajandi teine pool. 1966. Toim. Endel Nirk. Tallinn: Eesti Raamat.

EKNR = Marja Kallasmaa, Evar Saar, Peeter Päll, Marje Joalaid, Arvis Kiristaja, Enn Ernits, Mariko Faster, Fred Puss, Tiina Laansalu, Marit Alas, Valdek Pall, Marianne Blomqvist, Marge Kuslap, Anželika Šteingolde, Karl Pajusalu, Urmas Sutrop 2016. Eesti kohanimeraamat. Toim. Peeter Päll, Marja Kallasmaa. Tallinn: Eesti Keele Sihtasutus.

EKVT = Epp Ehasalu, Külli Habicht, Valve-Liivi Kingisepp, Jaak Peebo 1997. Eesti keele vanimad tekstid ja sõnastik. Tartu: Tartu Ülikool.

EM I = Eesti muinasjutud 1: 2. Imemuinasjutud. 2014. Koost. Risto Järv, Mairi Kaasik, Kärri Toomeos-Orglaan. Toim. Inge Annom, Risto Järv, Mairi Kaasik, Kärri Toomeos-Orglaan. Tartu: Eesti Kirjandusmuuseumi teaduskirjastus.

EMS III = Eesti murrete sõnaraamat 3, 2001. Toim. Anu Haak, Evi Juhkam, Varje Lonn, Helmi Neetar, Piret Norvik, Vilja Oja, Jüri Viikberg. [Tallinn:] Eesti Keele Instituut.

EMS V = Eesti murrete sõnaraamat 5, 2013. Toim. Mari-Liis Kalvik, Mari Kendla, Tiina Laansalu, Jüri Viikberg. [Tallinn:] Eesti Keele Instituut. 
EREJ 1866 = Eestirahwa ennemuistesed jutud. Rahwa suust korjanud ja üleskirjutanud Fr. R. Kreutzwald. 1866. (= Suomalaisen Kirjallisuuden Seuran Toimituksia 42.) Helsinki: Suomalaisen Kirjallisuuden Seura.

EREJ 1967 = Eesti rahva ennemuistsed jutud. Rahva suust korjanud ja üles kirjutanud F. R. Kreutzwald. 1967. Tekstikriitiline, täiendatud väljaanne. Eritoim. August Annist. Tallinn: Eesti Raamat.

ERL $=$ Eesti rahvalaulud. Antoloogia 1-4, 1969-1974. Toim. Ülo Tedre. Tallinn: Eesti Raamat.

Ernits, Enn 2017. Sõna haaval. Emakeelest tehiskeelteni. (= Eesti Teaduste Akadeemia Emakeele Seltsi toimetised 75.) Tallinn: Emakeele Selts.

GM = Külli Habicht, Valve-Liivi Kingisepp, Urve Pirso, Külli Prillop 2000. Georg Mülleri jutluste sõnastik. (= Tartu Ülikooli eesti keele õppetooli toimetised 12.) Tartu: Tartu Ülikool.

$\mathbf{G r}=$ Grimms Märchen. Alle Märchen der Brüder Grimm. https://www.grimmstories.com/de/grimm_maerchen/die_sieben_schwaben (12.01.2019).

$\mathbf{J G}=$ Johannes Gutslaff 1998 [1648]. Observationes grammaticae circa linguam Esthonicam. Grammatilisi vaatlusi eesti keelest. Tõlk. ja koost. Marju Lepajõe. (= Tartu Ülikooli eesti keele õppetooli toimetised 10.) Tartu: Tartu Ülikool.

JR = Valve-Liivi Kingisepp, Külli Habicht, Külli Prillop 2002. Joachim Rossihniuse kirikumanuaalide leksika. (= Tartu Ülikooli eesti keele õppetooli toimetised 22.) Tartu: Tartu Ülikool.

Järv, Risto 2005. Sehvtjeviiten ja seitse tõdemust. Isikunimedest muinasjuttudes. - Keel ja Kirjandus 6, 442-454; 7, 549-557.

$\mathbf{K K v}=$ Fr. R. Kreutzwaldi ja A. Schiefneri kirjavahetus 1853-1879. (= Fr. R. Kreutzwaldi kirjavahetus 3.) Tallinn: Eesti Riiklik Kirjastus.

$\mathbf{K N}=$ Eesti Keele Instituudi kohanimekartoteek. http://heli.eki.ee/kohanimed (10.03.2019).

Kp I = Friedrich Reinhold Kreutzwald 1961. Kalevipoeg. Tekstikriitiline väljaanne ühes kommentaaride ja muude lisadega. Tallinn: Eesti Riiklik Kirjastus.

Kreutzwald, Friedrich Reinhold 1953. Maailm ja mõnda. Tallinn: Eesti Riiklik Kirjastus.

Laugaste, Ed[uard] 1940. Kreutzwaldi muinasjutt „Lopi ja Lapi“. - Eesti Kirjandus 4, 179-182.

Luba $=$ Luba (Piirisilla) veski. http://weskiwiki.veskivaramu.ee/index.php?title= Luba_(Piirisilla)_veski (12.01.2019).

MK $=$ E[duard $]$ Laugaste, E[rna] Normann 1959. Muistendid Kalevipojast. (= Monumenta Estoniae Antiquae 2. Eesti muistendid. Hiiu- ja vägilasmuistendid 1.) Tallinn. Eesti Riiklik Kirjastus.

$\mathbf{M M}=$ Friedrich Reinhold Kreutzwald 1849. $\mathrm{Ma}=\mathrm{ilm}$ ja mõnda mis seal sees leida. Tartu. https://www.digar.ee/viewer/et/nlib-digar:222/21458 (12.01.2019). 
Mäemets, Aare 1977. Eesti NSV järved ja nende kaitse. Tallinn: Valgus.

Naumann, Horst, Gerhard Schlimpert, Johannes Schultheis 1984. Das kleine Vornamenbuch. Leipzig: VEB Bibliographisches Institut.

Name $=$ Behind the Name. https://www.behindthename.com/names/55 (02.06.2019).

Palmblad, Vilhelm Fredrik 1838. Biographiskt Lexicon öfver namnkunnige Svenska Män 4, Upsala: Leffler \& Sebell.

Rajandi, Edgar 2011. Raamat nimedest. Nimeseadus. 3. tr. Tammerraamat.

RAK = Rukkisaak Alutaga keskmine. 1926. - Postimees nr 220, 16. august. https://dea.digar.ee/article/postimeesew/1926/08/16/16 (12.01.2019).

Raun, Alo, Oliver Kund 2013. Muistse vabadusvõitluse ristisõjastajad pidasid maha sõnalahingu Vahtrega. - Postimees, 5. veebruar. https://arvamus.postimees.ee/1123866/muistse-vabadusvoitluse-ristisojastajadpidasid-maha-sonalahingu-vahtrega? gallery $=15660$ \&image $=1556916$ (12.01.2019).

Ring Salomos. Enzyklopädie des Islams. http://www.eslam.de/begriffe/r/ ring_salomos.htm (12.01.2019).

SV $=$ Salomo Heinrich Vestring 1998. Eesti-saksa sõnaraamat. Lexicon Esthonico Germanicum. Tartu: Eesti Kirjandusmuuseum.

VAKK = Vana kirjakeele korpus. http:/vakk.ut.ee (12.01.2019).

Vaskjala sild. https://et.wikipedia.org/wiki/Vaskjala_sild (12.01.2019).

VJ = [Uued ennemuistsed jutud.] Vinguv jalaluu. Ulmeantoloogia. 2018. Koost. Indrek Hargla. [Tallinn:] Raudhammas.

Warelius, Andreas 1849. Beiträge zur Kenntniss Finnlands in ethnographischer Beziehung (Aus dem XIII Bändchen der Beiträge zur Kenntniss des Russischen Reiches und der angrenzenden Länder Asiens; ausgegeben von K. E. v. Baer und G. v. Helmersen). St. Petersburg. http://www.doria. fi/bitstream/handle/10024/101727/Beitrage_zur_Kenntniss_Finnlan. pdf? sequence $=1$ \&isAllowed=y (12.01.2019).

Wied $=$ Ferdinand Johann Wiedemann 1973. Eesti-saksa sõnaraamat. 4., muutmata trükk teisest, Jakob Hurda redigeeritud väljaandest. Tallinn: Valgus.

WT $=$ Wastne Testament 2001 [1686]. [Tallinn:] Eesti Keele Sihtasutus.

$\tilde{\mathbf{O S}}=$ Tiiu Erelt, Tiina Leemets, Sirje Mäearu, Maire Raadik 2018. Eesti õigekeelsussõnaraamat ÕS 2018. Toim. Maire Raadik. Tallinn: Eesti Keele Sihtasutus. 


\title{
About proper names used in Old Estonian Fairy Tales by Friedrich Reinhold Kreutzwald
}

\author{
ENN ERNITS
}

The paper deals with proper names which occur in the collection Old Estonian Fairy Tales written by Friedrich Reinhold Kreutzwald, the author of the Estonian epic Kalevipoeg, and published for the first time in 1866 in Helsinki. The work includes 43 fairy tales and 18 local folk-tales. The main goal of the paper is systematic treatment of proper names. For this purpose, all possible toponyms and personal names have been localised and classified, had their use in the old written records identified, and as far as possible, had their etymology specified.

In Old Estonian Fairy Tales there occur 47 toponyms, among them 17 in the fairy tales and 30 in the local folk-tales. We can distinguish real places, among them countries, regions, approximately localisable places (for instance, Põhjamaa 'Northern land') and virtual places, like Kullamaa 'Gold country, Eldorado' and Kungla 'Eldorado' in the fairy tales. They most often contain country names (8), for example Soome $\sim$ Soomemaa 'Finland', Pohlamaa 'Poland' a. o. The folktales include mainly names of real places. The names of manors (7) and cities (5) are most frequent among them. The work includes 59 names of characters in the stories. Names from the fairy tales comprise the majority (56) of these. The collection includes 20 names of mythological persons (Ahti, Põhja konn 'Northern Frog' a. o.), 39 anthroponyms (Els, Une-Tõnu 'Sleepy Tõnu', Pahlen, etc.), and 4 zoonyms (dog names).

Keywords: Estonian language, toponyms, personal names, fairy tales, local folktales, Friedrich Reinhold Kreutzwald, onomastics, folkloristics, Estonian literature

\section{Enn Ernits}

veterinaarmeditsiini ja loomakasvatuse instituut

Eesti Maaülikool

Kreutzwaldi 62

51014 Tartu

enn.ernits@emu.ee 